\title{
Expansionary Fiscal Contractions: Re-evaluating the Danish Case
}

\author{
U. Michael Bergman* \\ Michael M. Hutchison ${ }^{\dagger}$
}

May 18, 2009

\begin{abstract}
The Expansionary Fiscal Contraction (EFC) hypothesis predicts that a major fiscal consolidation leads to an economic expansion under certain circumstances. We test this hypothesis, and the implied non-linear responses of the economy to large and small changes in fiscal policy, using data from the 1983 Danish fiscal reform. We use a structural VAR/event study methodology following Blanchard and Perotti (2002) that explicitly allows us to distinguish between normally marginal changes in fiscal policy and comprehensive fiscal reforms. We find that "marginal changes" in fiscal policy (expenditure and tax changes) have the expected Keynesian effects on output and consumption. However, we find no evidence that the large fiscal consolidation in Denmark slowed the economy after controlling for a host of exogenous shocks and business cycle effects: Rather, we find some support for the hypothesis that the exogenous fiscal contraction in Denmark was a credible regime shift and, together with other reforms undertaken at the time, increased both private consumption and aggregate output.
\end{abstract}

KEYWORDS: Expansionary fiscal contraction; structural VAR/event study; nonlinearities

JEL Classification Numbers: E21, E62, E65.

${ }^{*}$ Department of Economics, University of Copenhagen, Studiestræde 6, DK-1455, Copenhagen K, Denmark. Email: Michael.Bergman@econ.ku.dk

${ }^{\dagger}$ Department of Economics, University of California, Santa Cruz, CA 95064. Email: hutch@ucsc.edu We thank an anonymous referee and the editors of this journal for useful comments, Ninette Pilegaard Hansen and Dan Knudsen for data assistance, and Danmarks Nationalbank for generously providing the data. 


\section{Introduction}

The prospect of a fiscal contraction typically raises well-founded fears among policymakers - based on conventional macroeconomic analysis - over the likely recessionary consequences. This concern, for example, is widespread in France, Germany and elsewhere in Europe as EMU members struggle to meet the budget deficit limits of the Stability and Growth Pact. In theory, however, a major fiscal contraction which leads to the expectation of permanently lower future paths of government consumption and taxation could in some circumstances be expansionary. This non-Keynesian prediction has been termed the 'expansionary fiscal contraction hypothesis' (EFC) (Giavazzi and Pagano (1990)) and often characterized as the 'German view' in light of statements by the German Council of Economic Experts in the early 1980s that fiscal retrenchment should set the foundation for an economic expansion. ${ }^{1}$

Non-linearities in fiscal response functions or "trigger points" associated with large stabilizations are discussed by Blanchard (1987), Bertola and Drazen (1993), Sutherland (1997), Barry (1999), Perotti (1999), Giavazzi, Jappell and Pagano (2000) and others. The basic argument is that large fiscal consolidations lead to a revision in expectations about the future tax burden - future taxes are expected to be lower which in turn signals a rise in the present discounted value of wealth — and may also induce a supply-side response if taxes are distortionary. A key issue in this context is that the fiscal consolidation is viewed as credible and the reform will be followed systematically. By contrast, if the fiscal contraction does not lead to the expectation of significantly lower permanent government consumption expenditure levels, then the conventional negative aggregate demand effect

\footnotetext{
${ }^{1}$ Recent 'New Keynesian' models with price stickiness also predict that increases in government consumption financed by lump-sum taxation have negative effects on private consumption (Canzoneri, Cumby and Diba (2003) and Linnemann and Schabert (2003)). The argument is that government spending tends to reduce private wealth and thereby reduce the demand for private consumption. Linnemann and Schabert (2004) show, however, that the standard Keynesian effect re-emerges within these models if the elasticity of substitution between government and private consumption is low.
} 
may dominate. In this sense, there may be non-linearities in the response of the economy to particularly large (signifying a regime shift) and persistence changes in fiscal policy as contrasted with the effects of fiscal policy during normal circumstances.

In this context, the large Danish fiscal contraction that was announced in October 1982 with the formation of a new coalition government, and implemented in stages between 1983 and 1986, is a fascinating case study that has attracted considerable international attention for several reasons (e.g. Alesina and Perotti $(1996,1997)$, Barry and Devereux (1994,1995,2003), Bergman and Hutchison (1999) and Bertola and Drazen (1993)). Firstly, the Danish 'consolidation' was substantial and broad reaching in that it covered public sector spending, public sector wages, taxes and other features (see appendix A). It was also the most successful budget consolidation experienced in the OECD area to date. The actual budget deficit improved by 12.5 percent of GDP and the structural (cyclically adjusted) deficit improved by 9.5 percent of GDP over the three-year fiscal consolidation period. The actual budget position (structural budget position) was -9.1 percent $(-8.1$ percent) of GDP in 1982 — the year prior to the fiscal consolidation - and 3.4 percent (1.4 percent) during the last year of the consolidation in 1986.

Secondly, the economy experienced very strong output and consumption growth and a substantial reduction in unemployment during this period that provides prima facie evidence of a 'expansionary fiscal contraction.' Real GDP and consumption growth averaged 3.7 and 4.0 percent, respectively, during 1984-86 — the fastest growth period in Denmark since the 1960s. Unemployment also declined by 2.2 percentage points during the period.

Thirdly, the economy's strong performance was totally unexpected. It was widely anticipated that the fiscal contraction measures would have a significant adverse short run effect on the economy in line with standard Keynesian predictions. The Council of Economic Advisors in Denmark revised sharply downward (upward) their forecasts of output and consumption (unemployment) following the announcement of the economic package 
leading to fiscal austerity measures in late 1982. In particular, as shown in panel A of Table 1, the forecast for 1984 real GDP and consumption growth were revised downward by 1.7 percent and 0.6 percent respectively between October 1982 and May 1983. The unemployment forecast was increased by 1.5 percentage points. What actually occurred was, of course, quite different and the official forecasts greatly underestimated positive developments in the economy during 1984-86. Panel B, for example, shows that the year-ahead official forecasts (published in May 1983, November 1984 and December 1985) cumulatively underestimated GDP growth by 3.4 percent and consumption growth by 4.3 percent during 1984-86. Similarly, the official forecasts systematically overestimated the level of unemployment during this period. The economy was very strong by historical standards and moving in the opposite direct of what had been anticipated.

Empirical work supporting the EFC hypothesis and finding non-linearities include Alesina and Perotti (1995) Perotti (1999), Giavazzi, Jappelli and Pagano (2000) and Höppner and Wesche (2000). ${ }^{2}$ This view has not gone unchallenged for the Danish case, however. Andersen and Risager $(1990,1991)$ and Andersen (1994), for example, postulate another hypothesis for Denmark, based primarily on the idea that the decline in government spending was concentrated on non-tradable goods which in turn depressed real wages and increased international competitiveness. Similarly, Bergman and Hutchison (1999) find some support for the EFC hypothesis for Denmark, but attribute most of the rise in consumption at the time to a favorable terms-of-trade development and other factors increasing permanent income. Other explanations such as lower real interest rates associated with the adoption of a 'hard currency regime' have also been put forward as

\footnotetext{
${ }^{2}$ However, van Aarle and Garretsen (2003) focusing on EU countries and using the Giavazzi and Pagano methodology found no strong evidence in favor of EFC. Hjelm (2002), using panel data regressions, rejects the EFC hypothesis. A common result in the literature focusing on the general effects of fiscal policy is that government consumption tends to crowd in output (and private consumption), see e.g., Perotti (2004). For an excellent survey of the literature on the effectiveness of fiscal policy as well as on the EFC hypothesis, see Hemming, Kell and Mahfouz (2002).
} 
alternatives to the 'German view' of the unexpected expansions in Denmark and elsewhere following fiscal contractions.

In this paper, we develop a precise test of the EFC explanation that emphasizes nonlinearities in the response to the 1983 Danish fiscal reform. The innovation of our paper is to view the Danish fiscal reform as a particular historical event, contrasting the comprehensive government expenditure and tax changes of the reform as analytically distinct from the normally marginal changes in fiscal policy. This allows for a structural break and inherent non-linearities in the response of the economy to the fiscal reform in Denmark. Our "event study" approach, with the Danish fiscal reform as the centerpiece, is an extension of the Blanchard and Perotti (2002) structural VAR time-series event study statistical methodology.

Furthermore, as opposed to the earlier literature focusing on a cross-section of countries, we focus intensively on one episode. In their survey of the EFC literature, Hemming, Kell and Mahfouz (2002) write: "While these studies differ in terms of their samples and methodology, the approach adopted is broadly the same. Each study subjects a cross section of fiscal consolidation periods over a 10-35 year period to analysis with a view to identifying those with expansionary effects on activity, isolating the channels through which they occur, and describing some of their characteristics" (p. 22). By contrast, we focus our attention intensively on the Danish experience using a structural VAR/event study method.

Using this methodology, we are able to distinguish between a "normal" change in government consumption expenditures and taxes as opposed to a major policy action directed towards a significant and long-lasting fiscal consolidation such as that assumed by the EFC. We find that the 1983 Danish fiscal consolidation led to both a consumption and output boom as well as a large swing in the budget from deficit to surplus. This supports the EFC hypothesis. The model also suggests, however, that fiscal policy during "normal" 
times impacts consumption and output in the standard Keynesian way, i.e., a fall (rise) in government consumption expenditures (taxes) reduce consumption and output. These results are robust to changes in the model specification, assumptions about the trending behavior the variables, and to alternative identifying restrictions.

The paper is organized in the following manner. Section 2 sets out the empirical methodology that we apply to test the EFC hypothesis. In section 3 we present the empirical results. Section 4 contains robustness checks. Finally, section 5 provides some concluding comments.

\section{Empirical Model}

Our empirical methodology is designed to measure and distinguish the effects of fiscal policy actions during 'normal times' (marginal changes) and those associated with major fiscal consolidations ("non-normal" times). Following Blanchard and Perotti (2002), we combine a structural VAR with one akin to an event study. Structural VARs have been used in many contexts to study the effects of monetary and fiscal policy (e.g. Bernanke and Mihov, 1998), but we are not aware of other studies, other than Blanchard and Perotti, however, that have introduced the event study element into structural VARs and none tests the EFC hypothesis using this methodology. The advantage of this approach is that it allows us to measures the effects of major discretionary fiscal expenditure and tax measures (e.g. 1983 Danish fiscal consolidation) that are simply too large to be treated as realizations from the same underlying stochastic process and must be treated separately. We trace the effects of the large, one-time, change in Denmark's fiscal position by studying the dynamic response of output and consumption to an associated dummy variable that we include in the VAR specification.

Our basic model is a four variable structural VAR system comprised of taxes, govern- 
ment consumption, output and private consumption. This system allows us to analyze the dynamic responses of both output and private consumption - the key elements needed to test the EFC hypothesis - to shocks in taxes and government consumption during normal times. In a robustness test, we also extend the basic model by including the terms of trade since external factors have been considered by many as an important explanation for the boom in the Danish economy during the fiscal consolidation (e.g. Andersen and Risager, 1990).

We initially focus on taxes, government consumption, output and private consumption during "normal" times (and later introduce the dummy variable capturing "non-normal" times) and assume that these variables are generated by the following VMA system

$$
\Delta x_{t}=\delta+R(L) v_{t}
$$

where $x_{t}=\left[\begin{array}{cccc}T_{t} & G_{t} & Y_{t} & C_{t}\end{array}\right]^{\prime}$, where $L$ is the lag operator. All variables are in logarithms and are measured in real per capita terms. The structural shocks $v_{t}=\left[\begin{array}{llll}\psi_{T} & \psi_{G} & \psi_{Y} & \psi_{C}\end{array}\right]^{\prime}$ satisfies $\mathrm{E}\left[v_{t}\right]=0$, and $\mathrm{E}\left[v_{t} v_{t}^{\prime}\right]$ is diagonal, where $\psi_{i}$ is tax, government spending, income, and private consumption shocks respectively. The parameters in the lag polynomial $R(L)$ can be computed from estimates of the following VMA model

$$
\Delta x_{t}=\delta+C(L) \varepsilon_{t}
$$

where $C(L)=I_{4}+\sum_{j=1}^{\infty} C_{j} L^{j}$, and the four dimensional vector of innovations $\varepsilon_{t}$ is assumed to be a white noise sequence with $\mathrm{E}\left[\varepsilon_{t}\right]=0$ and a nonsingular covariance matrix $\mathrm{E}\left[\varepsilon_{t} \varepsilon_{t}^{\prime}\right]=\Sigma$. The basic problem is to identify the structural innovations $v_{t}$ in (1) as linear combinations of the reduced form disturbances $\varepsilon_{t}$ in (2), i.e., to find a matrix $F$ such that $v_{t}=F^{-1} \varepsilon_{t}$.

To identify our system, we follow the procedure suggested by Blanchard and Perotti 
(2002). Within our base model comprised of four variables, we define the following links between the structural shocks and the estimated residuals from the unrestricted VAR model above:

$$
\begin{aligned}
& \varepsilon_{t}^{T}=a_{1} \varepsilon_{t}^{Y}+a_{2} \psi_{t}^{G}+\psi_{t}^{T} \\
& \varepsilon_{t}^{G}=b_{1} \varepsilon_{t}^{Y}+b_{2} \psi_{t}^{T}+\psi_{t}^{G} \\
& \varepsilon_{t}^{Y}=c_{1} \varepsilon_{t}^{T}+c_{2} \varepsilon_{t}^{G}+\psi_{t}^{Y} \\
& \varepsilon_{t}^{C}=d_{1} \varepsilon_{t}^{T}+d_{2} \varepsilon_{t}^{G}+\psi_{t}^{C}
\end{aligned}
$$

where $a, b, c$, and $d$ are parameters. The first two relationships in (3) state that unexpected movements in taxes (within period $t$ ) are due to unexpected changes in output and structural shocks to government spending and taxes, whereas unexpected changes in spending are due to unexpected changes in output and structural shocks to taxes and spending. The next two equations state that (apart from structural shocks) there is a contemporaneous relationship between unexpected changes in output (and in private consumption) and unexpected changes in taxes and government spending.

To compute the parameters in (3), we follow the procedure outlined by Blanchard and Perotti with two exceptions. First, $a_{1}$ which measures the elasticity of taxes with respect to output is constructed by Blanchard and Perotti using disaggregated data on taxes. We set this parameter equal to 1.3 in our base case which, given the tax share of output in the Danish economy, implies that a one unit increase in output leads to a 0.6 units increase in taxes (corresponding to the average tax rate in the Danish economy). ${ }^{3}$ This can be compared to the estimate of $a_{1}$ used by Blanchard and Perotti which implies that on average a one dollar increase in output in the U.S. leads to a 35 cents increase in taxes.

\footnotetext{
${ }^{3}$ Giorno, Richardson, Roseveare and van den Noord (1995) report an output elasticity of income tax equal to 0.7 and of social security equal to 0.6 for the Danish economy in 1991.
} 
Secondly, the parameter $b_{1}$ measuring the elasticity of government expenditures to output is set to -0.2 in our base case. Blanchard and Perotti set this parameter equal to zero as they cannot identify any response of government spending following a change in output. We believe that the Danish economy is likely to be different in this respect. Given the large government sector it seems plausible to assume that there is an automatic response of government consumption when output changes. Giorno, Richardson, Roseveare and van den Noord (1995) report a value of this parameter for Denmark equal to -0.2 expressed as a percent of government expenditure. We use this measure in our base model.

The links between unexpected changes in taxes and spending, represented by the parameters $a_{2}$ and $b_{2}$, allow for both the possibility that spending responds to changes in taxes or vice versa. As Blanchard and Perotti point out, there is no convincing way to identify these two parameters from the correlation between taxes and spending. Therefore, we look at two cases, $\left(a_{2} \neq 0, b_{2}=0\right)$ and $\left(a_{2}=0, b_{2} \neq 0\right)$. It turns out that the empirical results below are not dependent on the ordering of the contemporaneous relationship between taxes and spending. Therefore, we only report the results using the latter identifying restrictions. Moreover, as in Blanchard and Perotti, we estimate the VMA model in (2) allowing each parameter in the lag polynomial to depend on a particular quarter. That is, the lag response are allowed to vary depending upon the particular quarter in question. The reason for allowing seasonal dependence in this way is the presence of seasonal patterns in the response of taxes to economic activity. Some taxes, such as excise and sales taxes, are collected immediately with changes in economic activity, while others such as corporate income taxes may be collected with considerable lag. These estimates are then used to calculate the parameters in the identifying matrix that identifies the system.

Note that this identification scheme only allows us to study the effects from tax and government consumption shocks. The remaining two shocks are not identified, i.e., the structural shocks to output and private consumption can not be separated using this iden- 
tification as these two shocks are correlated. ${ }^{4}$

The Danish fiscal consolidation, of course, may not be considered a "normal" period. To capture this key event, we introduce a dummy variable and measure its effects on output and private consumption separately from marginal changes in government spending and taxes. The main tax and expenditure measures of the Danish fiscal contraction, as shown in the appendix, were implemented in stages starting in early 1983 and concluding with the "Potato Diet" in 1986 (see Appendix A giving the chronology of Danish fiscal adjustments during this period). We therefore define a dummy variable that takes the value of unity during the 1983:1-1986:4 fiscal consolidation and zero otherwise. We also test an alternative model specification as a robustness check with a dummy variable reflecting the beginning of the fiscal consolidation — a dummy variable taking the value of unity in 1983:1 and zero otherwise. The inclusion of these dummy variables allows us to explicitly test whether the dynamics during the fiscal consolidation was indeed different from adjustment during normal times. In particular, we are interested in the question whether the dynamics are consistent with the expansionary fiscal contraction hypothesis as has been suggested in the earlier literature.

\section{Empirical results}

The data consists of quarterly observations on real taxes per capita (direct and indirect taxes plus social contribution minus subsidies), real government consumption per capita, real GNP per capita, and real private consumption per capita provided by Danmarks Nationalbank. ${ }^{5}$ The sample runs from 1971:1 to 2000:4. All variables are in logarithms and are seasonally adjusted. All results below are based on VAR models with 4 lags.

First, we consider the properties of the data. We have applied a variety of standard

\footnotetext{
${ }^{4}$ See Blanchard and Perotti (2002) for further details on the limitations of this identification scheme.

${ }^{5}$ We are indebted to Dan Knudsen who kindly made the data available to us.
} 
$\mathrm{ADF}$-tests to test whether our data series contain unit roots and if there are cointegration relationships in the data. The results, see Table 2, suggest that all four series contain unit roots with a possible exception of taxes regardless of how we specify the deterministic components. In the table we report ADF-tests using 4 augmenting terms but the results are insensitive to this choice. Similar results are obtained for other lag lengths as well. Furthermore, see the lower part of Table 2, there is no strong evidence suggesting any cointegration relationships between the four series. The ADF-test statistics suggest that we cannot reject the null hypothesis that there is no cointegration using taxes as the independent variable in the first stage of the Engle-Granger two step method. This conclusion also holds when using the other three variables as the independent variable and for other lag lengths in the augmenting term except when output is the independent variable and assuming a quadratic trend. Only in this latter case, we can reject the null of no cointegration at conventional significance levels. We have also applied Johansen's maximum likelihood based method but were unable to find any cointegration vector for models with linear trend in the data and for a model with quadratic trends. For these reasons we focus on a VAR model where we assume that all variables contain unit roots and where there is no cointegration vector in the data. ${ }^{6}$ This formulation of the model implies that all structural shocks have permanent long-run effects on the variables in the system, i.e. there is no constraint that brings the system back to an existing initial steady state level (or trend growth) equilibrium. Short-term behavior is also not restricted and the responses of the variables to various shocks are freely determined by the model estimates.

In the next three subsections we analyze the dynamic effects of the four structural shocks by examining impulse response functions of GDP and private consumption to tax and spending shocks. We also investigate if and how the Danish budget consolidation

\footnotetext{
${ }^{6}$ We have, however, also estimated models with a quadratic deterministic trend but the results were very similar as when assuming stochastic trends, i.e., when the variables are nonstationary but not cointegrated. These results are available from the authors upon request.
} 
during the 1980:s affected the Danish economy by computing the impulse responses of shocks to the dummy variable. Finally, we measure the importance of the consolidation dummy variable by using historical decompositions constructing forecasts of output and private consumption with and without the dummy variable in the VAR models. As a final check of our results, we perform some robustness tests where we extend our four variable model by including terms-of-trade and thereby conditioning the estimates of potential important external effects.

\subsection{Dynamic Behavior of Output and Consumption}

In Table 3 we report estimates of the contemporaneous coefficients in equation (3) for the VAR model with 4 lags and assuming stochastic trends but no cointegration. These parameters are estimated under the assumption that the elasticity of taxes with respect to output $a_{1}=1.3$ and assuming that the elasticity of government expenditures to output $b_{1}=-0.2$. In the first two columns of Table 3 we report the point estimates of the contemporaneous effects between taxes and government consumption $\left(a_{2}\right.$ and $\left.b_{2}\right)$. These parameters are in general quite small and not statistically significantly different from zero. This suggests that the ordering of taxes and government consumption is of minor importance, a result confirmed by the impulse response analysis.

The next two columns report the estimates of the elasticities of output with respect to taxes $\left(c_{1}\right)$ and government spending $\left(c_{2}\right)$. The estimated parameters have their expected (according to Keynesian theory) signs and they are precisely estimated (the t-statistics are relatively large). The same applies to the elasticities of private consumption with respect to taxes and government spending $\left(d_{1}\right.$ and $\left.d_{2}\right)$. A one unit increase in government spending leads to a 0.97 units increase in output whereas a unit increase in taxes leads to a reduction of output with 0.72 units. These results are consistent with the estimates using US data presented by Blanchard and Perotti. We also find that the contemporaneous effects from 
government consumption and taxes on $\operatorname{GDP}\left(c_{1}\right.$ and $\left.c_{2}\right)$ are larger in absolute values than the contemporaneous effects on private consumption $\left(d_{1}\right.$ and $\left.d_{2}\right)$.

As our results in Table 3 suggest that the ordering of taxes and government consumption is of minor importance for the impulse response analysis we only report results for the case when $a_{2} \neq 0$ and $b_{2}=0.7$

In Figure 1, we show the response of (log level) output and private consumption to a one unit structural positive shock to taxes and government spending. We have also included the one standard deviation confidence bands calculated using bootstrap simulation with 500 trials.

Looking first at the responses of GDP and private consumption to tax shocks shown in Figures 1(a) and 1(c), we find that the estimated effects have the conventional signs. A positive structural tax shock leads initially to a negative response of GDP and private consumption. The permanent negative effects visible in the graphs are given by assumption since we have assumed stochastic trends. Similarly, a positive shock to government spending leads to a positive response of both GDP and private consumption in the short-run, see Figures 1(b) and 1(d). There is an immediate positive impact on both output and private consumption following an increase in government spending, as predicted by conventional theory. Note, however, that the impulse responses of private consumption is significant only during the 10 quarters as opposed to the effect on output which is significant for all time horizons. These estimates seem to suggest that expansionary tax and spending policies, in line with conventional wisdom, may have expansionary effects on the economy during "normal" times. Furthermore, the effects from changes in government spending are stronger than the effects from changes in taxes. This is also consistent with earlier empirical evidence.

\footnotetext{
${ }^{7}$ Results using the alternative identifying restriction that $a_{2}=0$ and $b_{2} \neq 0$ are available from the authors upon request.
} 
Taken together, these results are consistent with the traditional view of fiscal policy where a tax reduction and an increase in government consumption stimulates the economy leading to higher aggregate demand, higher private consumption and ultimately higher production.

\subsection{Did Denmark experience an expansionary fiscal contraction?}

We now turn to our tests of the EFC hypothesis during "non-normal" times. To test this hypothesis we add a dummy variable equal to unity during the Danish fiscal consolidation 1983:1 to 1986:4 and zero otherwise as explained above. ${ }^{8}$ The dynamic responses of our endogenous variables to this dummy variable represent the implied reaction to the fiscal consolidation. In this respect, the impulse responses to the dummy allow us to distinguish between "normal" and "non-normal" times and to examine whether the behavior of GDP and private consumption was different during the Danish fiscal consolidation.

Figures 2(a) and 2(b) plot the responses of taxes and government consumption to the fiscal consolidation. Taxes and government consumption gradually converge to their new long-run levels, with taxes (government consumption) expected to be permanently higher (lower). These expectations form an important part of the Danish fiscal consolidation.

In terms of our maintained hypotheses, the two lower boxes in Figure 2 plot the impulse responses arising from a major fiscal consolidation. These results lend support to the EFC hypothesis. Major fiscal consolidation has a substantial short- and long-run positive effect on output and private consumption. There are initial consumption and output booms,

\footnotetext{
${ }^{8}$ An alternative approach is to allow all parameters in the VAR model to change during the fiscal consolidation period. We have performed a number of tests of parameter constancy and cannot reject the null hypothesis that the parameters are constant at the 5 percent level. In particular, we have tested whether the parameter during the fiscal consolidation period is equal to parameters before and after the consolidation, whether parameters before the consolidation are equal to parameters during and after the consolidation, whether the parameters before and during the consolidation are equal to parameters after the consolidation, and whether parameters before consolidation are equal to parameters after the consolidation allowing parameters during the consolidation to differ.
} 
followed by gradual convergence to more moderate increases in the longer-term steady state levels. Both GDP and private consumption reach their new long-run levels after about 12 quarters. This dynamic pattern and long-run response is consistent with the EFC hypothesis.

In terms of historical accuracy, these results are consistent with the particulars of the Danish fiscal consolidation (Bergman and Hutchison (1999)). The basic tenet of the Danish fiscal reform package was to encourage private sector activity and to lower public sector expenditures and raise selected taxes. The sharp improvement in the government budget position (12.6 percent of GDP) during 1983-86 was associated with both higher revenues (7.1 percent of GDP) and lower expenditures (5.5 percent of GDP). Expenditures were reduced by limiting public sector wages and social payments while the remaining improvement came from permanent tax increases, hikes in social security contributions, taxation of higher-yielding pensions and an increase in the maximum tax rates. These changes in fiscal positions affect the expectations of future disposable income. Permanently lower government consumption normally lead to an upward revision of disposable income whereas permanently higher taxes normally lead to an expectation of lower future disposable income. $^{9}$ The Danish budget position also improved much faster than expected, from a deficit of 9.1 percent of GDP in 1982 to a surplus of 3.4 percent of GDP in 1986.

Average growth of real disposable income was $1.20 \%$ per year during the fiscal consolidation period compared to $1.04 \%$ during the sample 1983 to 2000. This suggests that not only future disposable income as forecasted to increase as a result of the fiscal consolidation (and subsequent lower budget deficits), but current disposable income also increased. However, during the fiscal consolidation period we cannot distinguish between (higher) tax and (lower) government consumption effects on disposable income for two reasons. First,

\footnotetext{
${ }^{9}$ It may be the case that higher current taxes lead households to revise upward their expectations of future disposable income if this tax increase generates expectations of less dramatic, less disruptive and less distortionary future tax increases.
} 
there has only been one fiscal consolidation and one episode is only sufficient to tease out the combined effects of tax and government consumption changes rather than individual changes. Second, Statistics Denmark does not publish quarterly data on disposable income for the sample we examine.

One should also keep in mind that in our specification of the VAR model (under the assumption of unit roots but no cointegration), all shocks will have permanent effects on the levels of all included variables by assumption. This also applies to the impulse responses of the data to the fiscal consolidation. We can, thus, not draw conclusions on the permanence of the effects of a fiscal consolidation. Likewise, if we assume that all variables are stationary (around a linear or quadratic trend), there will by assumption be no long run effects on any variable in the system during normal and non-normal times.

\subsection{Importance of the fiscal consolidation}

The impulse response analysis in the previous section cannot be used to evaluate the importance of the consolidation dummy in comparison to the impulse responses of output and private consumption with respect to the structural shocks during "normal" times. However, the graphs in Figures 1 and 2 suggest that the responses of both output and private consumption during the Danish fiscal consolidation are significant and that these responses differ from the impulse responses during normal times. One way to test the explanatory power of the fiscal consolidation dummy is to compare forecasts of output (and private consumption) using the full estimated models with the forecasts excluding the fiscal consolidation effect. The dashed line in Figure 3 shows the forecast value of output and consumption from our model given all available information from 1982:1 (deterministic terms and lagged values of the dependent variables in the system) until 1986:4. Note that we plot the level of output and private consumption. The dotted lines show the forecasts of these two variables excluding the fiscal consolidation dummy and finally the solid line is 
actual output and private consumption. It should also be noted that the difference between the dashed line and the solid line indicates "unexpected" developments, i.e., the forecast errors, that are explained by the structural shocks emerging during the forecast sample.

Figures 3(a) and 3(b) show that the model predicts a very strong and permanent upturn in output and consumption following a major fiscal consolidation, based on information available immediately prior to the reform and announcement of the program. The forecast path without the fiscal consolidation is a substantially lower trend path for both output and consumption. The historical path (realized) of output in Denmark following announcement of the fiscal reform follows the model forecast path very closely. Actual consumption developments were lower than forecast values in the first two years, and then jumped quickly to the forecast path by 1996. These results are entirely consistent with the EFC hypothesis.

Our interpretation of the forecast behavior is that the the fiscal consolidation dummy variable we use in our empirical models explains a large portion of the developments of both output and private consumption, thus, supporting the view that output and private consumption react differently during "normal" and "non-normal" times. Our results are consistent with the view that there are non-linearities or "trigger points" associated with large fiscal consolidations such as the Danish fiscal reform in the early 1980's.

One important caveat is worth emphasizing, however. Our study suffers from the same limitations associated with any event study. A strict interpretation of the results would need to assume that the fiscal reform "event" was the dominating economic factor at the time other than the variables explicitly included in the model. Reform measures were in fact implemented in every quarter during the 1983:1 to 1986:4 period, but other factors may also have played a role. Bergman and Hutchison (1999) emphasize favorable terms-oftrade developments and Andersen (1994) and Andersen and Risager (1990,1991) emphasize increased international competitiveness associated with labor market developments. Al- 
though we have attempted to control for a multitude of economic shocks in measuring the "marginal" significance of the fiscal consolidation dummy variable, we can not rule out that other structural reforms enacted during this period also played a role. Nonetheless, as we see below, the results are robust to a number of modeling changes.

\section{Robustness}

We undertake two robustness checks in this section. Firstly, we assume that the dummy variable takes on the value one only in 1983:1 and zero otherwise. Secondly, we extend the basic 4-variable structural VAR model to include a terms-of-trade variable. The extension allows us to evaluate the impact of external shocks on the performance of the Danish economy during the period of fiscal consolidation as well as other times.

\subsection{A single period dummy variable}

The Danish fiscal stabilization was carried out in a series of steps over 1983-86, shown in the appendix. The basic framework and estimates reported above modeled the fiscal consolidation shock by a dummy variable equal to unity over the 1983:1-1986:4 period, during which time a number of specific tax, spending, pension, social security and public wage measures were implemented, and zero otherwise. An alternative representation of the fiscal consolidation shock is to introduce a single period dummy variable reflecting the point in time when the public recognized a credible and large fiscal consolidation package was to be implemented. Our historical reading of the episode suggests that sometime in early 1983 (1983:1) is probably a good staring point for this robustness check. We therefore define the dummy variable to be equal to one in 1983:1 and zero otherwise. In our estimated VAR model we allow for current value and three lags of the dummy for 1986:1.

It turns out that our results are robust to changes in the definition of the dummy 
variable, i.e., all earlier results are confirmed. In particular, as above our results suggest that shocks to changes in government spending and taxes have the standard dynamic effects on output and private consumption during "normal" times while the EFC hypothesis is not rejected during "non-normal" times. In Figure 5, we plot the impulse responses of output and private consumption to a one unit shock to the dummy variable. Note, however, that even though our point estimates are positive, the impulse responses of output and private consumption are not statistically significant. These impulse responses become statistically significant when allowing for more lags of the dummy variable in the VAR model. ${ }^{10}$

Our results are particularly noteworthy since the initial official forecasts predicted that output and private consumption would fall in response to the fiscal consolidation plan, and there was considerable uncertainty about the fiscal actions taken in the early 1983 which depended on the outcome of the wage negotiations (see Bergman and Hutchison, 1999).

\subsection{5 -variable VAR model}

In addition to the 4 -variable baseline model, we also estimate an extended model that incorporates the terms-of-trade allowing us to study the responses of the variables in our system to terms-of-trade shocks and study the effects of fiscal policies on output and private consumption given external influences. To identify this 5-variable model, we assume that (1) there is no contemporaneous feedback between the terms-of-trade and either taxes or government spending and (2) that private consumption shocks do not affect the terms-of-trade contemporaneously. This implies the following links between the

\footnotetext{
${ }^{10}$ Note that the impulse response of a one unit shock to the dummy variable in our base model corresponds to the impulse response of a unit shock to the dummy variable in this latter case when we define the dummy to be equal to one in 1986:1 and zero otherwise allowing for current value and 15 lags of this dummy in the estimated VAR model.
} 
structural shocks and estimated residuals from the unrestricted VAR model:

$$
\begin{aligned}
& \varepsilon_{t}^{T}=a_{1} \varepsilon_{t}^{Y}+a_{2} \psi_{t}^{G}+\psi_{t}^{T} \\
& \varepsilon_{t}^{G}=b_{1} \varepsilon_{t}^{Y}+b_{2} \psi_{t}^{T}+\psi_{t}^{G} \\
& \varepsilon_{t}^{Y}=c_{1} \varepsilon_{t}^{T}+c_{2} \varepsilon_{t}^{G}+c_{3} \varepsilon_{t}^{p}+\psi_{t}^{Y} \\
& \varepsilon_{t}^{C}=d_{1} \varepsilon_{t}^{T}+d_{2} \varepsilon_{t}^{G}+d_{3} \varepsilon_{t}^{p}+\psi_{t}^{C} \\
& \varepsilon_{t}^{p}=e_{1} \varepsilon_{t}^{Y}+\psi_{t}^{p}
\end{aligned}
$$

where $\varepsilon_{t}^{p}$ is the estimated residual from the equation with terms-of-trade, $e_{1}$ is the contemporaneous effect from GDP to terms-of-trade and $\psi_{t}^{p}$ is the structural terms-of-trade shock. ${ }^{11}$ This identification scheme implies that we allow for Danish GDP to affect termsof-trade contemporaneously and that terms-of-trade contemporaneously affect both GDP and private consumption.

Estimates of the parameters in equation (4) are shown in Table 4. Similarly to the estimates for the 4-variable model above, we find that there is no significant contemporaneous effect from terms-of-trade on GDP, i.e., the coefficient $c_{3}$ is close to zero and not statistically significant at conventional levels. The contemporaneous effect from GDP on terms-of-trade $\left(e_{3}\right)$ is significant and private consumption reacts contemporaneously to changes in the terms-of-trade, the parameter $d_{3}$ is positive and significantly different from zero. Therefore, we may conjecture that the dynamic behavior of this extended model could be significantly different.

Figure 4 plots the impulse responses within the 5-dimensional VAR models assuming stochastic trends and no cointegration. According to the graphs, there are only minor changes to the impulse response functions compared to the ones we obtained for the $4-$

\footnotetext{
${ }^{11}$ Unit root and cointegration tests suggest that we cannot reject the null that terms-of-trade contains a unit root and that there is no cointegration vector present in the 5 -dimensional system. These results are available from the authors upon request.
} 
variable systems above. As in the 4-variable models, a positive tax shock and a negative shock to government consumption lead to lower GDP and private consumption in the short-term. This is quite surprising as the external influences on the Danish economy during the fiscal consolidation were regarded important by several authors in the literature. We find, even though these developments were potentially important, that they were not important enough to alter our main conclusion, during "normal" times output and private consumption behave and react in the standard way whereas during "non-normal" times these indicators behave in a way consistent with the EFC hypothesis. As can be seen from the forecasts in Figures 4(g) and 4(h), the fiscal consolidation variable is still a very important factor explaining the booms in output and private consumption during the fiscal consolidation. These results support our earlier finding that the fiscal consolidation significantly influences the adjustment output and private consumption during the Danish fiscal consolidation.

\subsection{Other sensitivity tests}

In addition to the sensitivity test performed above, we have also examined how the addition of other macroeconomic shocks and business cycle effects affect our results and conclusions. We focus on three different variables, the nominal long-term interest differential against Germany, G-7 output gap and the first log difference of G-7 GDP.

It has been argued in the earlier literature (Andersen (1994)) that private consumption in Denmark is very sensitive to changes in interest rates and that the fall in the Danish interest rate contributed to the sharp rise in private consumption at the time of the reform. The Danish long-term interest differential against Germany fell sharply during the fiscal consolidation period, starting the first trading day following the approval of the fiscal reforms in October 1982.

The fiscal reform undertaken in Denmark in 1983 coincided with a very sharp upturn 
in the world economy. The world business cycle measured as the G-7 output gap was in an expansion phase from March 1983 until it reached its peak in 1990. It may well be the case that this upturn, together with the labor market reforms and the increased competitiveness in the Danish economy, contributed significantly to the sharp increase in both economic growth and private consumption.

In order to examine whether these three factors affect our results, we add one variable at a time to our 4 -variable and 5 -variable systems as exogenous variables. ${ }^{12}$ The results show that neither of these macroeconomic shocks or business cycle effects can explain the boost in Danish output and private consumption during the fiscal consolidation. There are only minor changes in the responses of output and private consumption to the fiscal consolidation dummy. The effects are positive, as in our base case, with narrow confidence bands. This holds for both 4 - and 5-variable models. Our interpretation is that the interest effect emphasized by Andersen (1994) can not fully explain the boom in Danish output and private consumption during the fiscal consolidation. Furthermore, controlling for business cycle effects, either by the inclusion of G-7 output gap or the change in $G-7$ GDP we find that the responses are still positive and significant. The upturn in the world economy at the time of the fiscal consolidation did have a positive impact on the Danish economy, but there is still a significant increase in Danish output and private consumption accounted for by our fiscal consolidation dummy.

As a final sensitivity test we consider the effects of changes in the parameters $a_{1}$ and $b_{1}$. The former parameter measures the elasticity of taxes with respect to output whereas the latter is the elasticity of government expenditures to output. In our base case we set $a_{1}=1.3$ and $b_{1}=-0.2$. It may be the case that these elasticities may change as a result of the fiscal consolidation and the question is how sensitive our results are to such changes. First, a change in these two parameters can only affect the impulse responses during

\footnotetext{
${ }^{12}$ The results are not shown here for brevity, but are available upon request from the authors.
} 
normal times, the impulse responses to the fiscal consolidation dummy are independent on the particular identification scheme and therefore also these two parameters. Second, we find that our results are relatively unchanged if $a_{1}$ and $b_{1}$ change. In particular, if we increase the parameter $a_{1}$ we find that the response of both output and consumption to tax shocks become more negative as compared to the responses reported in Figure 1 whereas the responses of these variables to government consumption shocks become less positive. The only difference is a level shift, the patterns are identical to the impulse responses in Figure 1. In case we decrease $b_{1}$ (it becomes more negative) we find that the responses of both output and consumption to both tax and government consumption shocks are relatively unchanged, there are only very minor differences between these responses and the ones shown in Figure 1.

\section{Conclusions}

Our results suggest that it is important to contrast normal changes in fiscal policy from a major consolidation/reform that has implications for years to come and is viewed as a critical policy shift both by governments, politicians and the private sector. The Danish fiscal reform starting in 1983 was remarkably successful in turning around the government's rapidly deteriorating budget position. Our empirical results also suggest that the fiscal contraction in Denmark had strong stimulative effects on both consumption and output. By contrast, marginal changes in government consumption expenditure and taxes - fiscal policy in 'normal' times - had the conventional effect on consumption and output, e.g., small government tax (expenditure) increases generally led to a reduction (expansion) in consumption and slowdown (rise) in economic activity. Non-linearities in fiscal response functions or "trigger points" associated with large stabilizations appear to be very important empirically. However, although we have controlled for a number of macroeconomic 
shocks occurring during the period of fiscal consolidation, we can not rule out that other structural reforms undertaken at the time also played a role. For this reason, we interpret our results cautiously but emphasize that — at the least — there is no evidence that the fiscal consolidation dampened the growth of either output or consumption.

Our work is the first to apply the structural VAR/event study methodology in testing the EFC hypothesis. Previous work is largely based on international cross-section studies and has led to mixed results. We believe that our methodology is particularly well suited to the 'natural experiment' of the Danish fiscal consolidation. Moreover, our study provides much stronger support for the EFC hypothesis in Denmark than the largely descriptive case studies of the Danish experience. We emphasize, however, that our support for the EFC hypothesis only applies to large and credible fiscal consolidations and it is not possible to fully disentangle the effects of other reforms that may also have played an important role. Fiscal contractions based on marginal changes in taxes and government expenditures are more likely to have depressing effects on the economy in line with conventional Keynesian predictions.

\section{References}

Alesina, A. and R. Perotti, (1995), "Fiscal Expansions and Fiscal Adjustments in OECD Countries," NBER Working Paper 5214.

Alesina, A. and R. Perotti, (1996), "Reducing Budget Deficits," Swedish Economic Policy Review, 3, 115-134.

Alesina, A. and R. Perotti, (1997), "Fiscal Adjustments in OECD Countries: Composition and Macroeconomic Effects," IMF Staff Papers, 44, 210-248.

Andersen, T. M., (1994), "Disinflationary Stabilization Policy — Denmark in the 1980s," in, Ảkerholm, J. and A. Giovannini, (eds.), Exchange Rate Policies in the Nordic Countries, Centre for Economic Policy Research, London. 
Andersen, T. M. and O. Risager, (1990), "Wage Formation in Denmark," in, Calmfors, L., (ed.), Wage Formation and Macroeconomic Policies in the Nordic Countries, Oxford University Press, Oxford.

Andersen, T. M. and O. Risager, (1991), "The Role of Credibility for the Effects of a Change in the Exchange-Rate Policy," Oxford Economic Papers, 43, 85-98.

Barry, F., (1999), "Comment," in, Andersen, T. M., S. E. H. Jensen and O. Risager, (eds.), Macroeconomic Perspectives on the Danish Economy, MacMillan, New York.

Barry, F. and M. B. Devereux, (1994), "The Macroeconomics of Government Budget Cuts: Can Fiscal Contractions be Expansionary," in, Robson, W. B. P. and W. M. Scarth, (eds.), Deficit Reduction: What Pain, What Gain?, C. D. Howe Institute, Toronto.

Barry, F. and M. B. Devereux, (1995), "The "Expansionary Fiscal Contraction" Hypothesis: A Neo-Keynesian Analysis," Oxford Economic Papers, 47, 249-264.

Barry, F. and M. B. Devereux, (2003), "Expansionary Fiscal Contraction: A Theoretical Exploration," Journal of Macroeconomics, 25, 1-23.

Bergman, U. M. and M. M. Hutchison, (1999), "Economic Expansions and Fiscal Contractions: International Evidence and the 1982 Danish Stabilization," in, Andersen, T., S. E. H. Jensen and O. Risager, (eds.), Macroeconomic Perspectives on the Danish Economy, MacMillan, New York.

Bernanke, B. S. and I. Mihov, (1998), "Measuring Monetary Policy," Quarterly Journal of Economics, 113, 869-902.

Bertola, G. and A. Drazen, (1993), "Trigger Points and Budget Cuts: Explaining the Effects of Fiscal Austerity," American Economic Review, 83, 1170-1188.

Blanchard, O. J., (1987), "Germany and the World Economy: A US View," Economic Policy, 1, 195-200.

Blanchard, O. J. and R. Perotti, (2002), "An Empirical Characterization of the Dynamic Effects of Changes in Government Spending and Taxes on Output," Quarterly Journal of Economics, 117, 1329-1368.

Canzoneri, M., R. Cumby and B. Diba, (2003), "New Views on the Transatlantic Transmission of Fiscal Policy and Macroeconomic Policy Coordination," in, Buti, M., (ed.), Monetary and Fiscal Policies in EMU, Cambridge University Press, Cambridge. 
Giavazzi, F., T. Jappelli and M. Pagano, (2000), "Searching For Non-Linear Effects Of Fiscal Policy: Evidence From Industrial and Developing Countries," European Economic Review, 44, 1259-1289.

Giavazzi, F. and M. Pagano, (1990), "Can Severe Fiscal Contractions Be Expansionary? Tales of Two Small European Countries," in, Blanchard, O. J. and S. Fischer, (eds.), NBER Macroeconomics Annual, MIT Press, Cambridge.

Giorno, C., P. Richardson, D. Roseveare and P. van den Noord, (1995), "Estimating Potential Output Gaps and Structural Budget Balances," OECD Working Paper No. 152.

Hemming, R., M. S. Kell and S. Mahfouz, (2002), "The Effectiveness of Fiscal Policy in Stimulating Economic Activity - A Review of the Literature," IMF Working Paper No. $02 / 208$.

Hjelm, G., (2002), "Is Private Consumption Growth Higher (Lower) During Periods of Fiscal Contractions (Expansions)?," Journal of Macroeconomics, 24, 17-39.

Höppner, F. and K. Wesche, (2000), "Non-Linear Effects of Fiscal Policy in Germany: A Markov-Switching Approach," Bonn Econ Discussion Paper 9/2000.

Linnemann, L. and A. Schabert, (2003), "Fiscal Policy in the New Neoclassical Synthesis," Journal of Money, Credit and Banking, 35, 911-929.

Linnemann, L. and A. Schabert, (2004), "Can Fiscal Spending Stimulate Private Consumption?," Economics Letters, 82, 173-179.

Perotti, R., (1999), "Fiscal Policy in Good Times and Bad," Quarterly Journal of Economics, 114, 1399-1436.

Perotti, R., (2004), "Estimating the Effects of Fiscal Policy in OECD Countries," IGIER (Innocenzo Gasparini Institute for Economic Research), Bocconi University, Working Paper No. 276.

Sutherland, A., (1997), "Fiscal Crises and Aggregate Demand: Can High Public Debt Reverse the Effects of Fiscal Policy?," Journal of Public Economics, 65, 147-162.

van Aarle, B. and H. Garretsen, (2003), "Keynesian, Non-Keynesian or No Effects of Fiscal Policy Changes? The EMU Case," Journal of Macroeconomics, 25, 213-240. 


\section{Appendix A: A chronology of Danish fiscal adjustments.}

\begin{tabular}{|c|c|c|}
\hline Date & Announcement & Planned fiscal action \\
\hline $1982: 3 / 9$ & $\begin{array}{l}\text { The Social Democratic } \\
\text { government resigns }\end{array}$ & \\
\hline $1982: 10 / 9$ & $\begin{array}{l}\text { A new minority right-wing } \\
\text { coalition government (the } \\
\text { Conservative, the Liber- } \\
\text { als, the Centre Democrats } \\
\text { and the Christian Party) is } \\
\text { formed. }\end{array}$ & \\
\hline $1982: 16 / 10$ & $\begin{array}{l}\text { Economic-political com- } \\
\text { promise: }\end{array}$ & $\begin{array}{l}\text { I: Income-political part including: } \\
\text { - } \text { suspension of index-regulated raises for public employees (with effect from } \\
\text { the regulations that takes place after October 1983). } \\
\text { - } \text { suspension of "high-price regulation", indexation of wages, salary and transfer } \\
\text { income (until February 1985). } \\
\text { - Profits freeze of goods sold in the country (private sector). } \\
\text { - A total wage stop (from October } 1982 \text { until end February 1983.) }\end{array}$ \\
\hline & & $\begin{array}{l}\text { II: Fiscal-political part including: } \\
\text { - } \text { suspension of price indexation of some social payments (in } 1983 \text { and 1984). } \\
\text { - The first day of sickness is not covered by Social insurance (from April 1983). } \\
\text { - The contribution to unemployment insurance is raised from } 3.75 \text { to } 6 \text { times } \\
\text { the benefit rate for wage salary earners and from } 3.25 \text { to } 11.25 \text { times for } \\
\quad \text { employers. } \\
\text { - Rules for supplementary unemployment insurance benefits are tightened. } \\
\text { - Retirement pensions are set according to income level. } \\
\text { - Price-indexation of income taxes and personal allowances are suspended. } \\
\text { - The income tax ceiling is raised from } 70 \text { to } 73 \% \text {. } \\
\text { - Wealth tax deduction raised to } 1.158 .900 \mathrm{Dkr} .\end{array}$ \\
\hline
\end{tabular}

\begin{tabular}{|c|c|c|}
\hline $1983: 9 / 3$ & $\begin{array}{l}\text { New agreement on the la- } \\
\text { bor market is accepted. }\end{array}$ & \\
\hline $1983: 1 / 6$ & $\begin{array}{l}\text { Tax on pension funds, life } \\
\text { insurance etc. introduced. } \\
\text { Real return on bond hold- } \\
\text { ings exceeding } 3.5 \% \text { taxed } \\
\text { away (for the aggregate } \\
\text { pension fund sector). }\end{array}$ & \\
\hline $1984: 3 / 11$ & $\begin{array}{l}\text { General election: the } \\
\text { right-wing minority gov- } \\
\text { ernment continues }\end{array}$ & \\
\hline $1984: 17 / 5$ & $\begin{array}{l}\text { Economic-political com- } \\
\text { promise }\end{array}$ & $\begin{array}{l}\text { Including: } \\
\text { - Suspension of 'high-price regulation' continued until } 1987 . \\
\text { - 'Sickness Fund' contribution increased from } 0.15 \% \text { to } 2 \% \text {. } \\
\text { - Unemployment insurance contribution increased for wage salary earners. }\end{array}$ \\
\hline $1985: 31 / 3$ & $\begin{array}{l}\text { Economic-political com- } \\
\text { promise: On the back- } \\
\text { ground of the break down } \\
\text { of the general agreement } \\
\text { negotiations. }\end{array}$ & $\begin{array}{l}\text { Working week is reduced } 1 \text { hour (with wage compensation) and the wage of public } \\
\text { employees raised by } 1.75 \text { and } 1.25 \% \text { during the next two years. } \\
\text { - The corporate tax is raised from } 40 \text { to } 50 \% \text {. } \\
\text { - Persons younger than } 67 \text { years with income above } 150.000 \mathrm{Dkr} \text { in } 1984 \text { are } \\
\text { requested to make a 'bounded saving' for a limited period. }\end{array}$ \\
\hline
\end{tabular}




\begin{tabular}{|c|c|c|}
\hline Date & Announcement & Planned fiscal action \\
\hline $1986: 27 / 2$ & $\begin{array}{l}\text { 'EF-pakken' (the EC- } \\
\text { package) is adopted. }\end{array}$ & \\
\hline $1986: 18 / 3$ & Tax reform & $\begin{array}{l}\text { Income is divided into personal income and capital income. Personal } \\
\text { income is taxed progressive whereas capital income is (almost) taxed } \\
\text { proportional. } \\
\text { - Marginal tax rates reduced from } 72 \text { to } 68 \text { percent for personal } \\
\text { income and to approximately } 50 \text { for capital income. }\end{array}$ \\
\hline $1986: 21 / 3$ & $\begin{array}{l}\text { Raised duties } \\
\text { from } \\
\text { April } 1986\end{array}$ & Duties are raised on energy and luxury goods. \\
\hline $1986: 4 / 6$ & Wage Indexation Law. & 'High-price' wage indexation removed entirely. \\
\hline $1986: 17 / 10$ & The Potato Diet: & $\begin{array}{l}20 \% \text { tax on consumer credit interest payments imposed. Tightening } \\
\text { of regulation regarding credit purchases. Changes in law about mort- } \\
\text { gage loans, effectively reducing tax credits for interest deductions. } \\
\text { Increased energy duties. }\end{array}$ \\
\hline
\end{tabular}

Source: Økonomisk-politisk kalender, Statisktisk ti-års oversigt. Danmarks statistik. 
Table 1: Official forecasts published by the Economic Council 1982-85 and actual developments in the Danish economy.

\begin{tabular}{|c|c|c|c|}
\hline \multicolumn{4}{|c|}{$\begin{array}{l}\text { Panel A: Official forecast revisions } \\
\text { for } 1984 \text { following fiscal contraction }\end{array}$} \\
\hline & $\Delta Y$ & $\Delta C$ & $U$ \\
\hline Forecast 1982:10 & 3.0 & 2.4 & 10.4 \\
\hline Forecast 1983:5 & 1.3 & 1.8 & 11.9 \\
\hline Forecast Revision & -1.7 & -0.6 & 1.5 \\
\hline
\end{tabular}

\begin{tabular}{llrrr}
\hline \multicolumn{5}{c}{$\begin{array}{c}\text { Panel B: Official forecast errors } \\
\text { following fiscal contraction }\end{array}$} \\
\hline \multirow{4}{*}{1984} & \multicolumn{1}{c}{$\Delta Y$} & $\Delta C$ & \multicolumn{1}{c}{$U$} \\
\hline \multirow{1}{*}{1985} & Actual & 3.5 & 2.1 & 10.2 \\
& 1983:5 Forecast & 1.3 & 1.8 & 11.9 \\
& Forecast Error & -2.2 & -0.3 & 1.7 \\
& Actual & 3.6 & 4.0 & 9.2 \\
& 1984:11 Forecast & 3.0 & 2.4 & 10.3 \\
& Forecast Error & -0.6 & -1.6 & 1.1 \\
Actual & 4.0 & 5.9 & 8.0 \\
& 1985:12 Forecast & 3.4 & 3.5 & 8.7 \\
& Forecast Error & -0.6 & -2.4 & 0.7 \\
\hline
\end{tabular}

Source: Dansk Økonomi (Det Økonomiske Råd), various issues and Eurostat.

Table 2: Augmented Dickey-Fuller unit root and cointegration tests.

\begin{tabular}{lccc}
\hline \hline Variable & $\tau_{\mu}$ & $\tau_{\tau}$ & $\tau_{\gamma}$ \\
\hline Taxes & -3.67 & -0.75 & -1.92 \\
Government consumption & -2.11 & -1.86 & -1.57 \\
Output & -0.13 & -2.79 & -3.05 \\
Private consumption & -0.98 & -3.11 & -3.44 \\
\hline $5 \%$ Critical value & -2.92 & -3.46 & -3.88 \\
\hline Cointegration test & -1.00 & -0.89 & -4.05 \\
\hline $5 \%$ Critical value & -4.22 & -4.57 & -4.95 \\
\hline \hline
\end{tabular}

Note: $\tau_{\mu}$ is the ADF-test with a constant, $\tau_{\tau}$ with a constant and a linear trend and $\tau_{\gamma}$ with a constant and a second order polynomial trend. All ADF-tests are computed using 4 lags in the augmented terms. When testing for cointegration we let taxes be the independent variable in the cointegration regression.

Table 3: Estimated contemporaneous coefficients in equation (3). Stochastic trends model.

\begin{tabular}{cccccc}
\hline \hline$a_{2}$ & $b_{2}$ & $c_{1}$ & $c_{2}$ & $d_{1}$ & $d_{2}$ \\
\hline-0.205 & -0.037 & -0.717 & 0.971 & -0.358 & 0.674 \\
$(-0.942)$ & $(-0.942)$ & $(-5.781)$ & $(5.103)$ & $(-2.569)$ & $(3.160)$ \\
\hline \hline
\end{tabular}

Note: T-ratios are reported in parentheses below each coefficient estimate. 
Table 4: Estimated contemporaneous coefficients in equation (4). Stochastic trends model.

\begin{tabular}{ccccccccc}
\hline \hline$a_{2}$ & $b_{2}$ & $c_{1}$ & $c_{2}$ & $d_{1}$ & $d_{2}$ & $c_{3}$ & $d_{3}$ & $e_{3}$ \\
\hline-0.184 & -0.036 & -0.689 & 0.980 & -0.141 & 0.503 & -0.057 & 0.382 & 0.209 \\
$(-0.871)$ & $(-0.871)$ & $(-5.313)$ & $(5.117)$ & $(-1.113)$ & $(2.684)$ & $(-0.476)$ & $(3.276)$ & $(2.038)$ \\
\hline \hline
\end{tabular}

Note: T-ratios are reported in parentheses below each coefficient estimate.

Figure 1: Impulse response of output $(Y)$ and private consumption $(C)$ to a one standard deviation shock to taxes $(T)$ and government consumption $(G)$ during "normal" times.

(a) Response of $Y$ to a $T$ shock

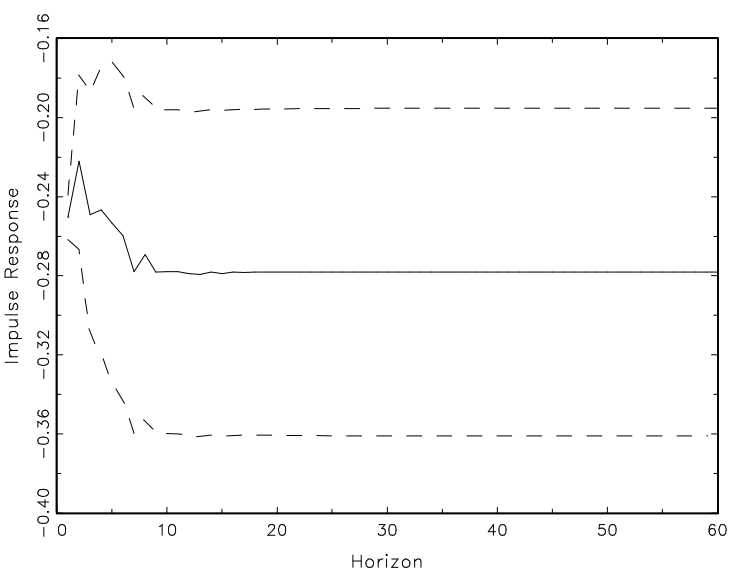

(c) Response of $C$ to a $T$ shock

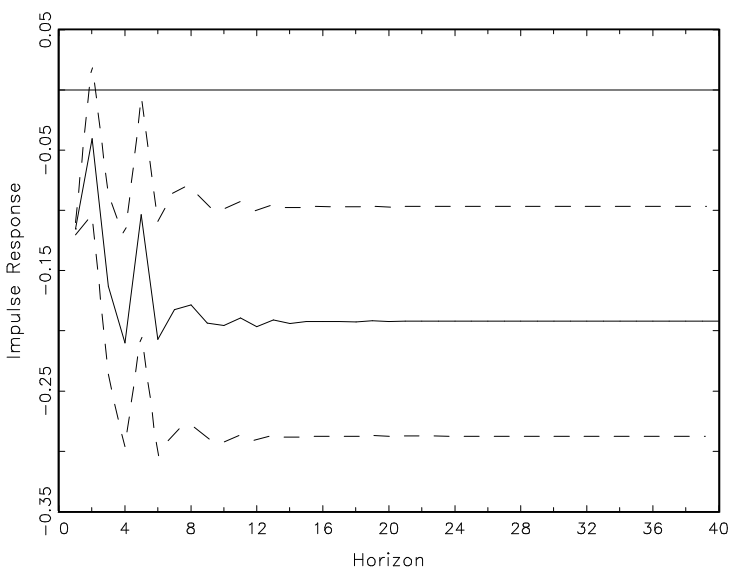

(b) Response of $Y$ to a $G$ shock

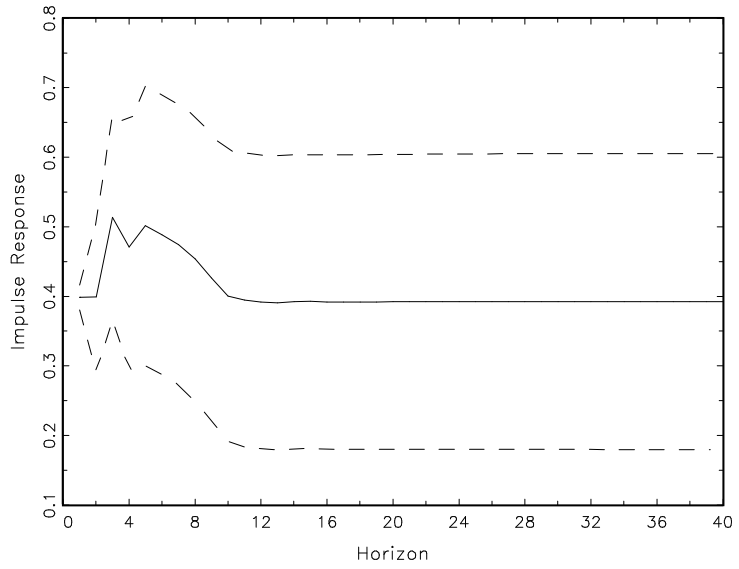

(d) Response of $C$ to a $G$ shock

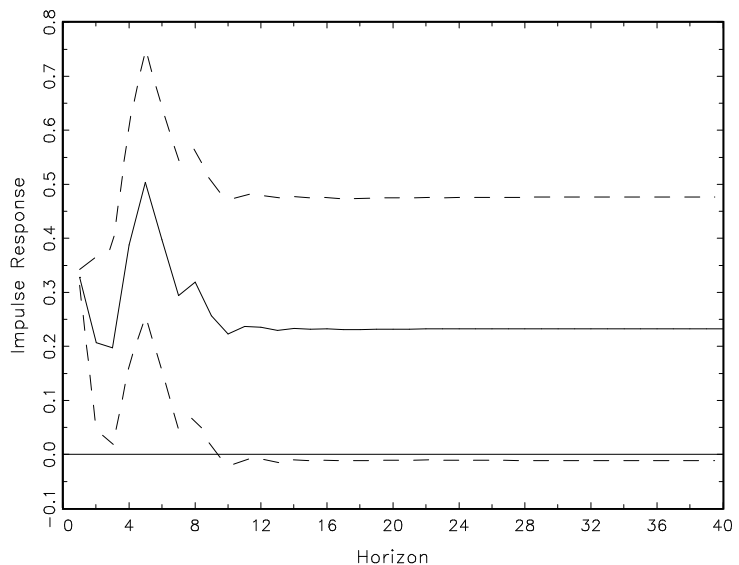

Note: One standard deviation confidence bands (dashed lines) are calculated using bootstrap simulations with 500 trials. 
Figure 2: Impulse response of taxes, government consumption, output and private consumption to a major fiscal consolidation.

(a) Taxes

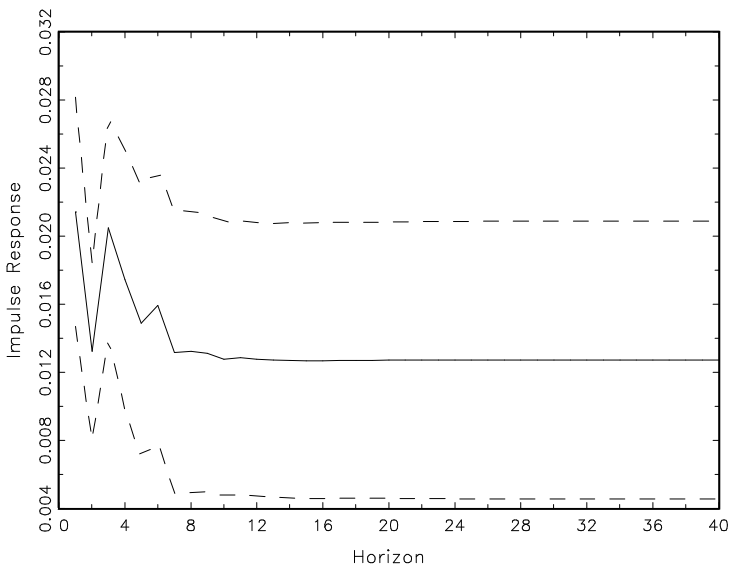

(c) Output

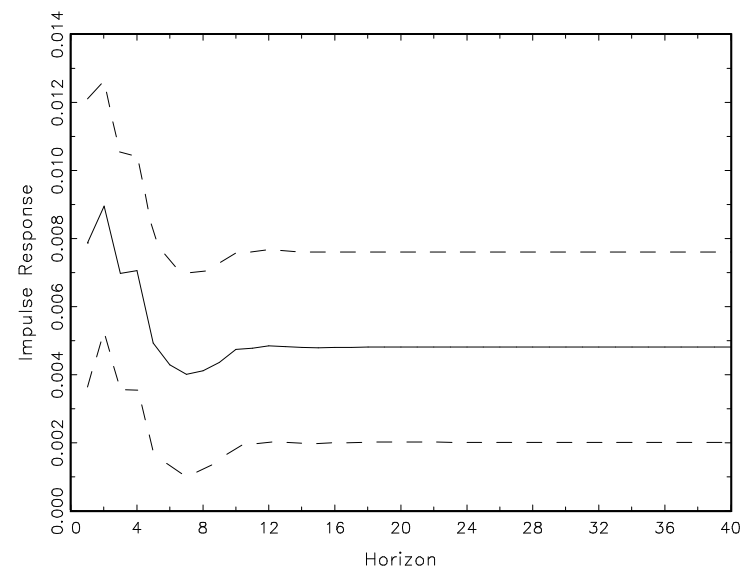

(b) Government consumption

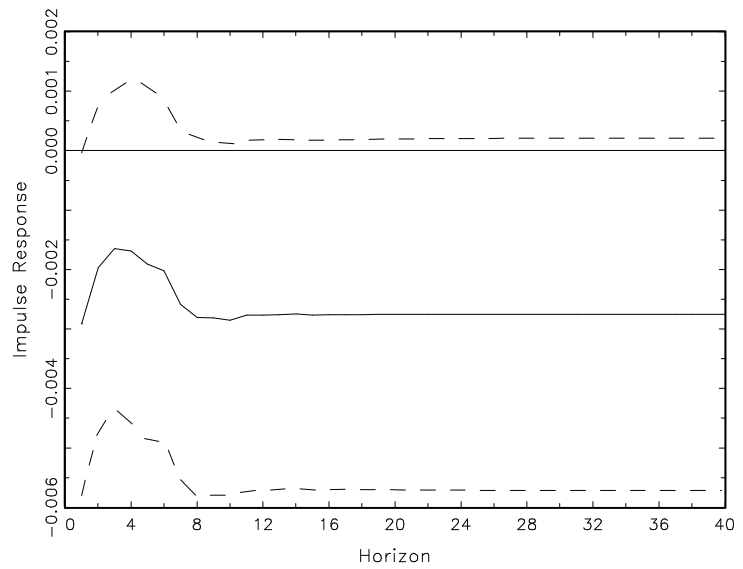

(d) Private consumption

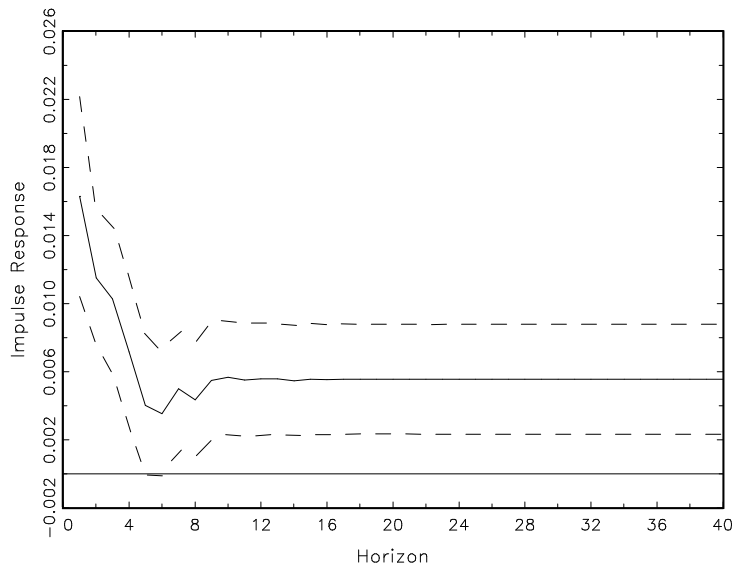

Note: One standard deviation confidence bands (dashed lines) are calculated using bootstrap simulations with 500 trials. 
Figure 3: Forecasts of output and private consumption with and without a major fiscal consolidation.

(a) Output

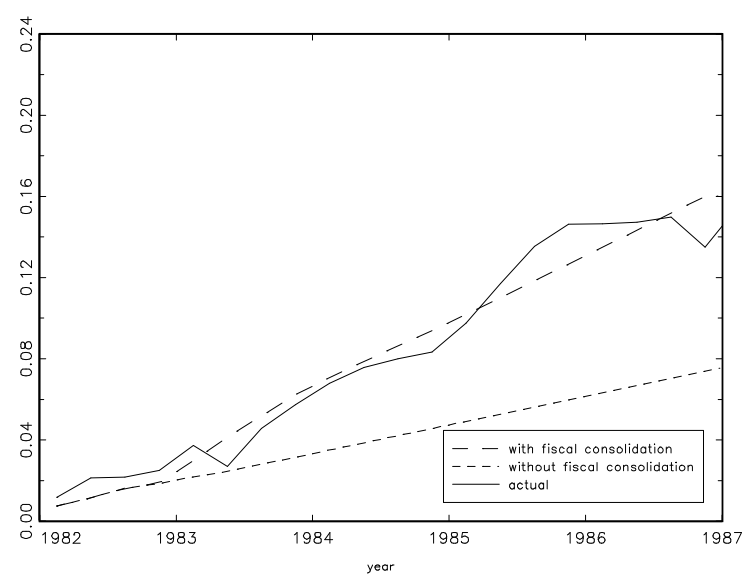

(b) Private consumption

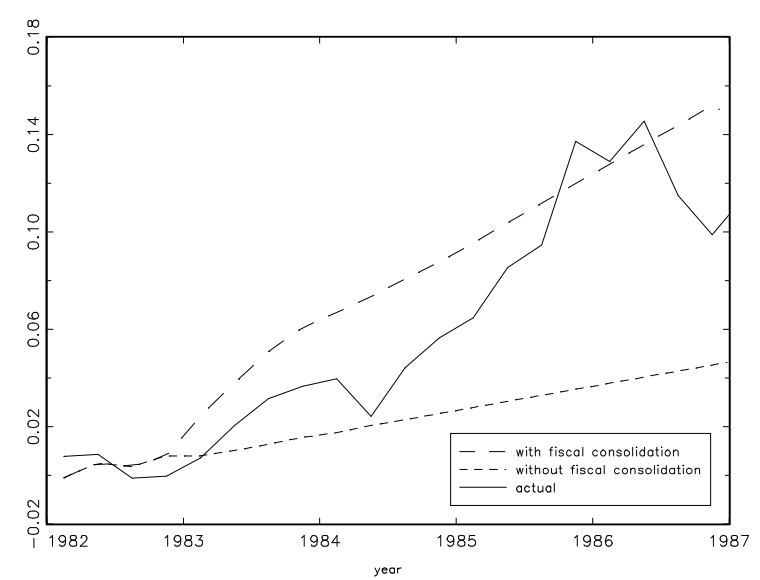




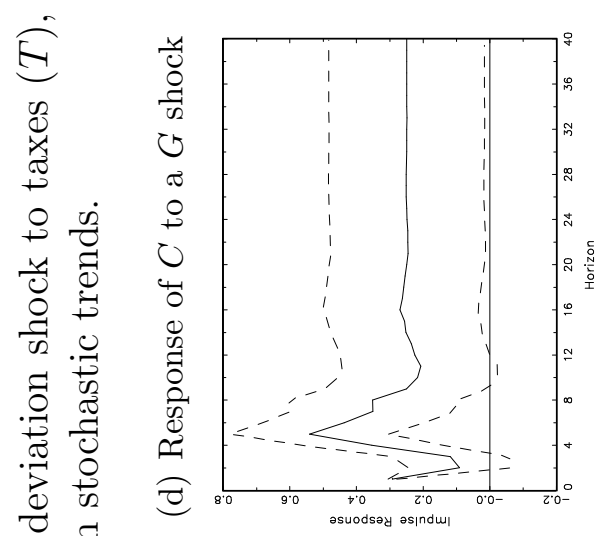

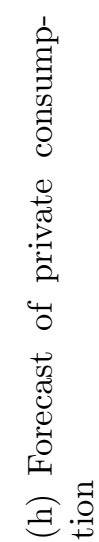

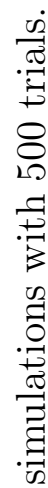
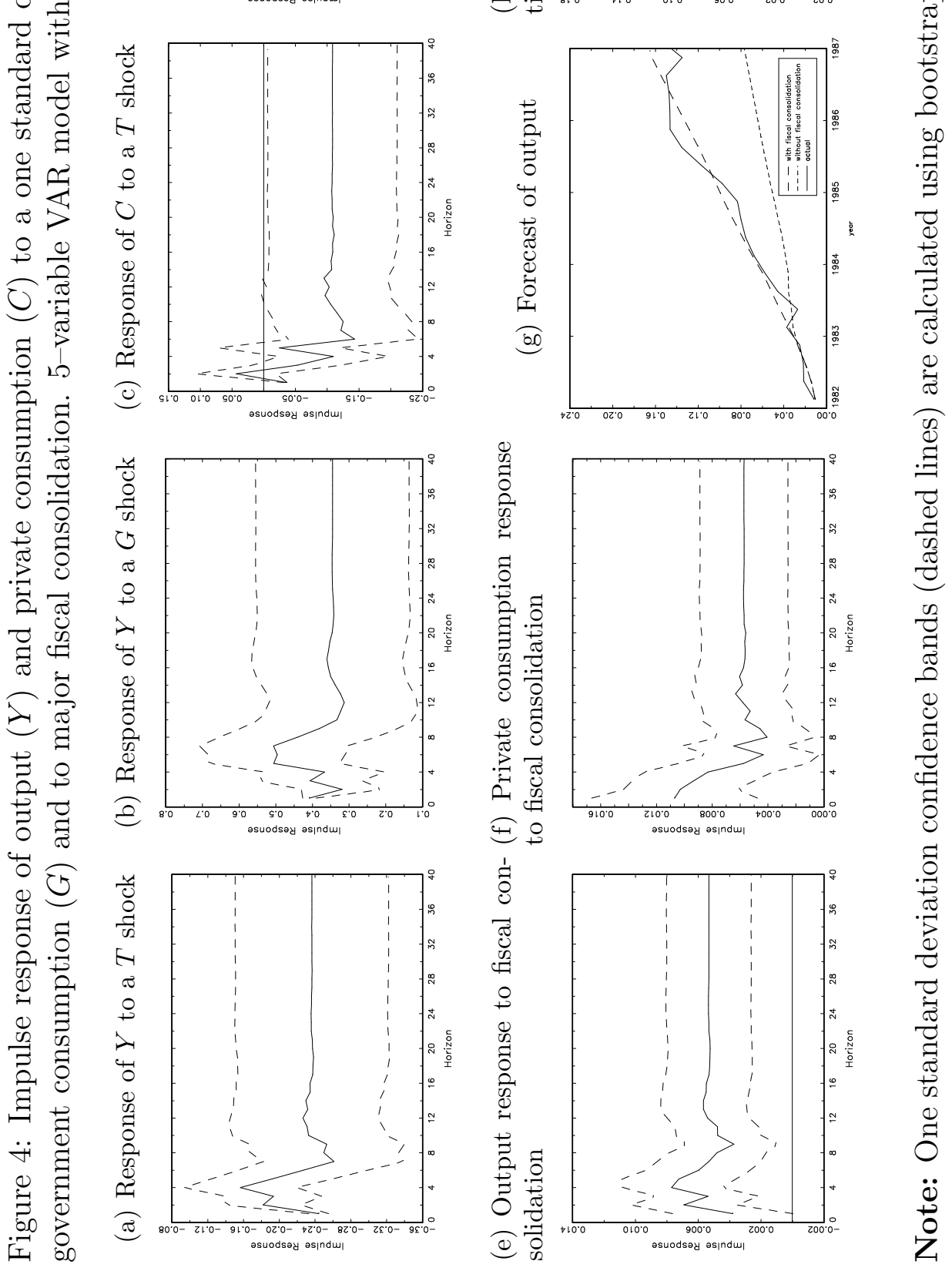

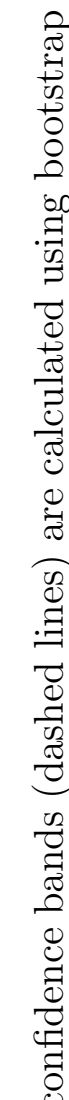

芫

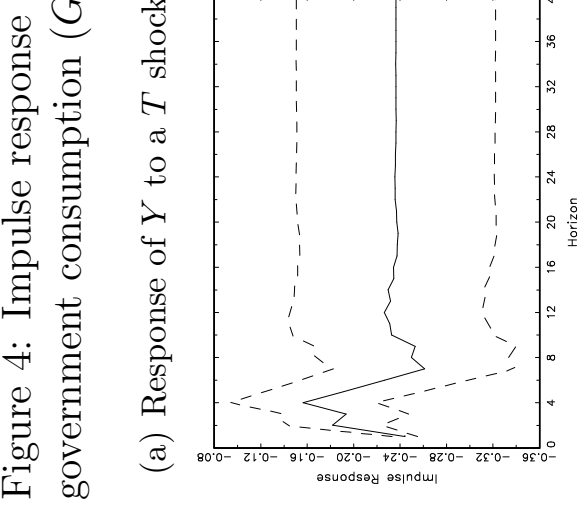


Figure 5: Impulse response of output and private consumption to a one unit shock to the 1983:1 dummy.

(a) Output

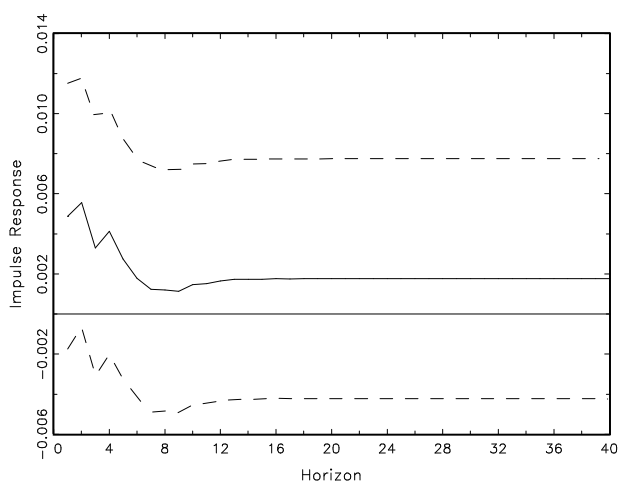

(b) Private consumption

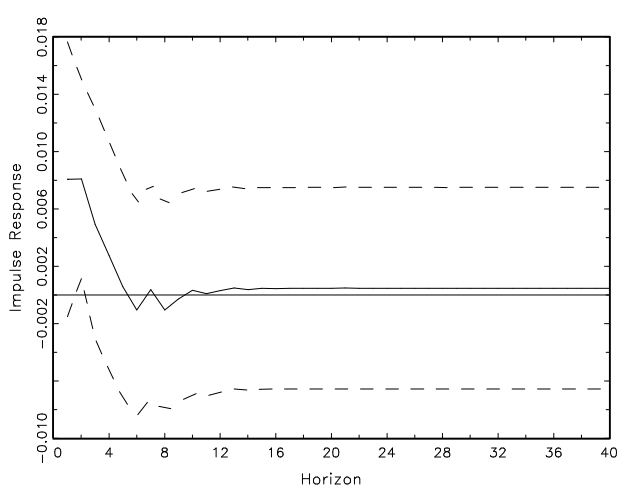

